\title{
Pengaruh Penggunaan Campuran Daun Ubi Kayu dan Ampas Tahu yang Difermentasi dengan Rhizopus oligosporus Sebagai Pengganti Sebagian Ransum Komersil terhadap Kualitas Karkas Broiler
}

\section{The Effect of the Utilization of Cassava Leaf and Tofu Dreg Mixture Fermented with Rhizopus oligosporus as the Replacer of Some Parts of Commercial Rations on the Carcass Quality of Broilers}

\author{
Annisa $^{1}$, Y. Rizal ${ }^{2 *}$, Mirnawati ${ }^{2}$, I. Suliansyah ${ }^{3}$, dan A. Bakhtiar ${ }^{4}$ \\ ${ }^{1}$ Program Pascasarjana Ilmu Pertanian, Universitas Andalas, Padang - Indonesia \\ ${ }^{2}$ Fakultas Peternakan, Universitas Andalas, Padang - Indonesia \\ ${ }^{3}$ Fakultas Pertanian, Universitas Andalas, Padang - Indonesia \\ ${ }^{4}$ Fakultas Farmasi, Universitas Andalas, Padang - Indonesia \\ *Corresponding E-mail: yrizal@ansci.unand.ac.id \\ (Diterima: 17 Januari 2020; Disetujui: 4 Mei 2020)
}

\begin{abstract}
ABSTRAK
Tujuan dari penelitian ini untuk mengetahui pengaruh level penggunaan campuran daun ubi kayu dan ampas tahu yang difermentasi dengan $R$. oligosporus (DUKATF) sebagai pengganti sebagian ransum komersil terhadap kualitas karkas ayam broiler. Penelitian ini dilakukan dengan menggunakan rancangan acak lengkap (RAL) dengan 5 perlakuan dan 4 ulangan. Setiap ulangan terdiri dari 5 ekor ayam. Perlakuan yang diberikan adalah: $\mathrm{A}=0 \% \mathrm{DUKATF}, \mathrm{B}=5 \% \mathrm{DUKATF}, \mathrm{C}=10 \% \mathrm{DUKATF}, \mathrm{D}=15 \%$ DUKATF, dan $\mathrm{E}=20 \%$ DUKATF. Peubah yang diamati yaitu bobot hidup, persentase lemak abdomen, dan persentase karkas broiler. Hasil penelitian menunjukkan bahwa perlakuan berpengaruh sangat nyata $(\mathrm{P}<0,01)$ terhadap bobot hidup, persentase lemak abdomen, dan persentase karkas. Bobot hidup pada perlakuan A, B, dan C berbeda tidak nyata $(\mathrm{P}>0,05)$, tetapi perlakuan $\mathrm{A}, \mathrm{B}$ dan $\mathrm{C}$ ini berbeda nyata $(\mathrm{P}<0,05)$ dengan perlakuan $\mathrm{D}$ dan $\mathrm{E}$, dan perlakuan $\mathrm{D}$ dan $\mathrm{E}$ berbeda tidak nyata $(\mathrm{P}>0,05)$. Persentase lemak abdomen perlakauan A berbeda nyata $(\mathrm{P}<0,05)$ dengan perlakauan $\mathrm{B}, \mathrm{C}, \mathrm{D}$, dan $\mathrm{E}$, tetapi antara perlakuan $\mathrm{B}, \mathrm{C}, \mathrm{D}$, dan $\mathrm{E}$ ini tidak berbeda nyata. Persentase karkas perlakuan A berbeda nyata $(\mathrm{P}<0,05)$ dengan perlakuan $\mathrm{B}, \mathrm{C}$, dan $\mathrm{D}$, namun perlakuan $\mathrm{A}$ ini tidak berbeda nyata $(\mathrm{P}>0,05)$ dengan perlakuan E. Pemberian DUKATF sampai 15\% tidak menurunkan persentase karkas. Kesimpulan penelitian yaitu penggunaan DUKATF bisa menggantikan sebagian ransum komersil sampai $15 \%$ pada ayam broiler.
\end{abstract}

Kata kunci: bobot hidup, DUKATF, persentase karkas, persentase lemak abdomen

\section{ABSTRACT}

Objective of this study to determine the effect of the level of use of a mixture of cassava leaves and tofu pulp fermented with Rhizopus oligosporus (DUKATF) as a substitute for a portion of the commercial ration to carcass quality. This study was conducted using a completely randomized design (CRD) with five treatments and four replications. Each test consisted of 5 chickens. The treatments given were: $A=0 \%$ DUKATF, $B=5 \%$ DUKATF, $C=10 \%$ DUKATF, $D=15 \%$ DUKATF and $E=20 \%$ DUKATF. Measured variables: body weight, percentage of abdominal fat, and percentage of broiler carcass. The results showed that the treatment had a very significant effect $(P<0,01)$ on body weight, percentage of abdominal fat, and percentage of the carcass. Bodyweight in treatment $A, B$, and $C$ was not significantly affected $(P>0,05)$. Still, treatments $A, B$, and $C$ were significantly affected $(P<0,05)$ with treatments $D$ and $E$, and treatments $D$ and $E$ differed not significant $(P>0,05)$. Percentage of abdominal fat treatment $A$ significantly affected $(P<0,05)$ with treatment $B, C, D$, and $E$, but between treatments $B, C, D$, and $E$ were not significantly affected. Percentage of carcass $A$ significantly affected $(P<0,05)$ from treatments $B$, $C$, and $D$, but this treatment $A$ did not significantly affect $(P>0,05)$ from treatment $E$. The giving DUKATF up to $15 \%$ does 
JPI Vol. 22 (2): 199-210

not reduce the percentage of carcasses. In conclusion, thus, the use of DUKATF replacing a portion of commercial rations can reach $15 \%$ in broiler chickens.

Keywords: body weight, DUKATF, percentage of the carcass, percentage of abdominal

\section{PENDAHULUAN}

Daun ubi kayu (DUK) sangat potensial dijadikan pakan ternak. Ketersediaannya cukup banyak. Produksi ubi kayu di Sumatra Barat mencapai 201.833 ton, sedangkan di Indonesia mencapai 19.341.233 ton (BPS, 2018). Tanaman ubi kayu ini di Indonesia ditanam pada lahan seluas $792.952 \mathrm{Ha}$ (BPS, 2018). Produksi daun ubi kayu segar per Ha menurut Sudaryanto et al. (1982) dalam Yuniza et al. (2016) berkisar antara 7-15 ton. Berdasarkan luas lahan tanaman ubi kayu dan produksi daun ubi kayu per hektar di atas, maka ketersediaan daun ubi kayu segar sebagai pakan ternak cukup melimpah yaitu berkisar antara 8,54-18,30 juta ton atau sekitar 2-4 juta ton dalam keadaan kering per tahunnya. Berdasarkan jumlah tersebut, kalau sekiranya separuh saja dari produksi daun ubi kayu kering yang terendah dimanfaatkan sebagai pakan ayam yaitu sebanyak 1 juta ton, maka diperkirakan akan dapat memenuhi kebutuhan pakan sekitar 274 juta ekor ayam petelur selama setahun, jika daun ubi kayu ini dipakai $8 \%$ untuk penyusun ransum bersama bahan pakan lainnya.

Potensi DUK sebagai bahan pakan alternatif dalam hal kandungan gizi. Kandungan nutrisi DUK adalah sebagai berikut: bahan kering (BK) 25,30\%, protein kasar (PK) 25,1\%, serat kasar (SK) 11,4\%, lemak mentah $12,7 \%$, retensi nitrogen 46 , $1 \%$ dan abu 9,1\% (Iheukwumere et al., 2008). Di sisi lain, DUK memiliki faktor pembatas sebagai bahan pakan alternatif. Penggunaan DUK dalam ransum ayam broiler hanya dapat digunakan hingga 5\% karena pemanfaatan hingga 10 dan 15\% dapat mengurangi efisiensi penggunaan pakan (Wyllie and Chamanga, 1979; Melesse et al., 2018). Penggunaan DUK dalam ransum ayam broiler masih terbatas karena SK tinggi, tanin,
HCN, kecernaan rendah (Ravindran, 1991) dan defisiensi asam amino yang mengandung belerang, terutama metionin (Eggum, 1970). Karena itu, penggunaan DUK masih terbatas. Untuk lebih meningkatkan jumlah DUK dalam ransum unggas, fermentasi fisik, kimia dan biologis harus dilakukan.

Fermentasi biologis dengan menggunakan mikroba adalah proses aktivitas mikroorganisme atau mikroba yang dapat menghasilkan produk yang tekstur, rasa, bau, dan kualitas nutrisinya berubah lebih baik daripada bahan baku (Mirnawati et al., 2019a; Mirnawati et al., 2019b; Dewi et al., 2019; Mirnawati et al., 2018; Mirrnawati et al., 2017; Adrizal et al., 2017; Mirnawati et al., 2013; Rizal et al., 2013; Rizal et al., 2012; Mirnawati et al., 2012; Aisjah, 2012; dan Mirnawati et al., 2010). Menurut Sugiharto (2019) fermentasi padat menggunakan jamur bisa menjadi metode sederhana untuk meningkatkan kualitas nutrisi pulp singkong dan dengan demikian meningkatkan produksi produk sampingan agroindustri yang murah dalam ransum ayam. Menurut Han et al. (2003) Rhizopus oligosporus menghasilkan protease, lipase, alpha-amylase, glutaminase, dan alpha-galactosidase dan (Dewi, 2015) menemukan bahwa Rhizopus oligosporus juga memproduksi selulase. Kehadiran enzim ini diharapkan dapat mengurangi anti-nutrisi dan racun yang terkandung dalam DUK dan juga meningkatkan nilai gizi mereka (Sumiati et al., 2011) sehingga meningkatkan penggunaan DUK dalam ransum ayam broiler.

Untuk meningkatkan produktivitas Rhizopus oligosporus dalam memproduksi enzim hidrolitik (protease dan selulase) dan untuk meningkatkan aktivitas enzim, perlu untuk memproduksi inokulum Rhizopus oligosporus dari dedak padi (DP) dan DUK sebagai penginduksi. Oleh karena itu, kemampuan enzim hidrolitik untuk degradasi 
PK dan SK dari DUK diharapkan meningkat. Penambahan DUK hidrolitik Rhizopus oligosporus (Soeprijanto et al., 2008; Zakaria et al., 2013). Rhizopus oligosporus akan dapat mensintesis enzim yang diperlukan untuk metabolisme sesuai dengan ketersediaan induser dalam starter (Kurnia, 2010; Purkan et al., 2016). Disamping itu penambahan ampas tahu (AT) sebagai kombinasi substrat DUK dapat memberikan kecukupan sumber nitrogen pada proses fermentasi (Nuraini et al., 2009). Pemberian perlakuan-perlakuan tersebut diharapakan dapat meningkatkan nilai manfaat daun ubi kayu sebagap bahan pakan alternatif serta mempertahankan kandungan betakarotennya.

Betakaroten diharapkan dapat meningkatkan kualitaskarkas dengan perannya menurunkan kolesterol dan menghambat pembentukan perlemakan abdomen. Hubungan pengaruh lemak abdominal tinggi terhadap kualitas karkas menunjukkan hubungan korelasi positif kandungan lemak karkas adalah cerminan penumpukan lemak yang berlebihan pada ayam broiler (Chambers et al., 1983; Suparti et al., 2019; Avrianti et al., 2019). Penimbunan lemak abdominal pada ayam broiler merupakan hasil ikutan dan penghamburan energi ransum, juga menyebabkan menurunnya berat karkas yang dapat dikonsumsi (Griffiths et al., 1978; Avrianti et al., 2019). Kualitas karkas yang baik akan terlihat pada kondisi perlemakan yang baik yaitu rendahnya persentase lemak abdominal sebagaimana yang telah diketahui bahwa lemak abdominal adalah hasil ikutan yang dapat mempengaruhi kualitas karkas. Oleh karena itu semakin rendah persentasi lemak abdominal maka semakin baik pula karkas yang diperoleh. Hal ini sesuai dengan Yuniastuti (2002) bahwa tinggi rendahnya kualitas karkas broiler ditentukan dari jumlah lemak abdominal yang terdapat pada broiler tersebut. Mahfudz et al. (2009) menyatakan bahwa lemak abdominal dan lemak karkas memiliki hubungan korelasi positif, yaitu apabila lemak abdominal meningkat maka lemak karkas juga akan meningkat dan sebaliknya bila lemak abdomem menurun maka lemak karkas juga menurun, maka kualitas karkas akan meningkat. Semakin rendah lamak abdomen maka semakin bagus kualitas karkas.

\section{METODE}

Bahan yang digunakan dalam penyusunan ransum adalah DUKATF hasil olahan terbaik dari proses fermentasi dengan inokulum R. oligosporus (Annisa et al., 2020a; Annisa et al., 2020b) dan ransum komersil CP Bravo 511. Ternak penelitian menggunakan DOC CP 707 dari strain Arbor acres campuran jantan dan betina sebanyak 100 ekor.

Perlengkapan kandang yang digunakan dalam penelitian ini adalah kandang box dari kawat yang berukuran $75 \times 75 \times 75 \mathrm{~cm}$ per unitnya. Masing-masing unit ditempati oleh 5 ekor ayam. Kandang dilengkapi dengan tempat pakan dan minum yang ditempatkan di luar kandang dan lampu listrik 60 watt untuk setiap kandang box sebagai sumber pemanas dan penerang di malam hari. Timbangan Ohaus kapasitas 2.610 gram untuk menimbang ransum, dan timbangan digital merek Camry EK 5055 untuk menimbang berat karkas.

Penelitian ini menggunakan perlakuan produk DUKATF menggantikan sebagian ransum komersil CP Bravo 511 dengan beberapa level pemberian. Rancangan yang digunakan adalah rancangan acak lengkap (RAL) dengan 5 perlakuan dan 4 ulangan. Setiap ulangan terdiri dari 5 ekor ayam. Perlakuan yang diberikan adalah: $\mathrm{A}=0 \%$ DUKATF, $\mathrm{B}=5 \%$ DUKATF, $\mathrm{C}=10 \%$ DUKATF, $\mathrm{D}=15 \%$ DUKATF, dan $\mathrm{E}=$ $20 \%$ DUKATF. Kandungan gizi dan energi metabolisme bahan pakan penyususun ransum perlakuan dapat dilihat pada Tabel 1 . Komposisi dan kandungan gizi serta energi metabolisme ransum perlakuan dapat dilihat pada Tabel 2.

\section{Tahapan Penelitian \\ Persiapan Ransum Penelitian}

Bahan penyusun ransum terdiri dari 
JPI Vol. 22 (2): 199-210

Tabel 1. Kandungan gizi dan energi metabolisme bahan pakan penyususun ransum perlakuan

\begin{tabular}{lrrrrrrrr}
\hline \multirow{2}{*}{ Bahan Pakan } & \multicolumn{10}{c}{ Kandungan Gizi bahan pakan } \\
\cline { 2 - 9 } & PK & LK & SK & Ca & P & ME & Met & Lis \\
\hline Bravo 511 (a) & 21,50 & 5,00 & 5,00 & 0,90 & 0,60 & 3.025 & 0,50 & 1,00 \\
Minyak sawit & 0,00 & 100,00 & 0,00 & 0,00 & 0,00 & 8.600 & 0,00 & 0,00 \\
Topmix & 0,00 & 0,00 & 0,00 & 0,60 & 0,00 & 0 & 0,00 & 0,00 \\
DUKATF (b) & 26,45 & 5,61 & 13,38 & 0,44 & 0,08 & 2.268 & 0,00 & 0,00 \\
DL-Metionin & 0,00 & 0,00 & 0,00 & 0,00 & 0,00 & 0 & 99,00 & 0,00 \\
L-Lisin & 0,00 & 0,00 & 0,00 & 0,00 & 0,00 & 0 & 0,00 & 99,00 \\
\hline
\end{tabular}

Keterangan: (a) Label CP Bravo 511 Charoen Phokphan, (b) Laboratorium Nutrisi Non-Ruminansia

Tabel 2. Komposisi dan kandungan gizi ransum perlakuan

\begin{tabular}{lrrrrr}
\hline \multirow{2}{*}{ Bahan Pakan } & \multicolumn{5}{c}{ Komposisi ransum perlakuan } \\
\cline { 2 - 6 } & $\mathrm{A}$ & $\mathrm{B}$ & $\mathrm{C}$ & $\mathrm{D}$ & $\mathrm{E}$ \\
\hline Bravo 511 & 100,00 & 93,15 & 87,56 & 81,88 & 75,99 \\
Minyak sawit & 0,00 & 0,75 & 1,25 & 1,85 & 2,65 \\
Topmix & 0,00 & 1,00 & 1,00 & 1,00 & 1,00 \\
DUKATF & 0,00 & 5,00 & 10,00 & 15,00 & 20,00 \\
DL-Metionin & 0,00 & 0,03 & 0,07 & 0,10 & 0,12 \\
L-Lisisn & 0,00 & 0,07 & 0,13 & 0,18 & 0,24 \\
\hline Jumlah & 100,00 & 100,00 & 100,00 & 100,00 & 100,00 \\
\hline Kandungan Gizi Ransum & \multicolumn{5}{c}{} \\
\hline PK & 21,50 & 21,35 & 21,47 & 21,57 & 21,63 \\
LK & 5,00 & 5,69 & 6,19 & 6,79 & 7,57 \\
SK & 5,00 & 5,33 & 5,72 & 6,10 & 6,48 \\
Ca & 0,90 & 0,87 & 0,84 & 0,81 & 0,78 \\
P Tersedia & 0,60 & 0,56 & 0,53 & 0,50 & 0,47 \\
ME & $3.025,00$ & $2.995,55$ & $2.982,96$ & $2.975,97$ & $2.980,14$ \\
Metionin & 0,50 & 0,50 & 0,50 & 0,50 & 0,50 \\
Lisin & 1,00 & 1,00 & 1,00 & 1,00 & 1,00 \\
B-Caroten & 0,00 & 0,00 & 0,00 & 0,00 & 0,00 \\
\hline
\end{tabular}

produk olahan daun ubi kayu atau DUKATF dan Ransum komersil CP Bravo 511, disusun dua kali dalam seminggu dengan cara diaduk sendiri. Ransum yang diberikan disusun secara iso-protein dan iso-energi, yaitu protein kasar 21,50\% dan ME $3.000 \mathrm{kkal} / \mathrm{kg}$.

\section{Sanitasi dan Persiapan Perlengkapan Kandang}

Membersihkan kandang dan mensucihamakan dengan cara pengapuran dan penyemprotan dengan Rhodalon. Persiapan perlengkapan kandang dan alat-alat penelitian seperti tempat makan dan minum, plastik penampung kotoran dan penerang. Pembersihan dan pembuangan kotoran dilakukan setiap 3 hari.

\section{Penepatan Ternak dalam Kandang}

Ayam ditimbang berat badannya sebelum ditempatkan secara acak pada unit kandang perlakuan. Ternak di timbang sekitar 10 skor mewakili dari sekitar 100 ekor yang akan dipakai dalam penelitian, lalu dicari berat rata-rata dari 10 ekor ternak ini yang akan dijadikan sebagai berat patokan/standar dan berat ternak terendah serta tertinggi. Disediakan kotak sebanyak lima buah 
untuk menepatakan ternak sesuai dengan berat badannya. Pada kelima kota tersebut ditempatkan dengan berat patokan berada ditengah dan dua tingkat berat berada di dua kotak untuk berat ternak lebih rendah dari berat patokan dan dua tingkat berada di dua kotak untuk berat yang lebih tinggi dari berat patokan susun kotak tersebut sebagai berikut: 100 ekor anak ayam broiler umur sehari (DOC) ditimbang 10 ekor untuk berat patokan yang diperoleh dari 10 ekor yaitu $40 \mathrm{~g}$, terendah $36 \mathrm{~g}$ dan tertinggi $45 \mathrm{~g}$, maka perbedaan berat terendah dan tertinggi dibagi menjadi 5 kelompok, yaitu 36-37 g, 38-39 g, 40-41 g, 42-43 g, 44-45 g. Selanjutnya ayam ditimbang berat badan ayam lainnya dan masuk kedalam kotak yang tersedia dan diberi warna untuk membedakannya sampai 100 ekor. Setelah itu anak ayam dimasukan kedalam box perlakuan.

Ayam ditempatkan sebanyak 5 ekor pada masing-masing unit perlakuan. Berat badan ayam diseragamkan berdasarkan ulangan. Setiap unit kandang diberi kode perlakuan dan ditempatkan secara acak. Dimulai dari kotak yang berisi anak ayam yang paling ringan diberi tanda warna biru, lalu ayam dimasuk kedalam kandang perlakaun. Dimulai kandang nomor satu, dua, tiga dan seterusnya sampai dua puluh terisi anak ayam satu ekor dengan tanda warna biru. Selanjutnya anak ayam dimasukan dari kandang perlakuan nomor dua puluh, Sembilan belas, ke satu. Demikian seterusnya pengisian kandang dengan anak ayam dilakukan secara bolak balik sampai seluruh unit kandang terisi masing-masing 5 ekor anak ayam dengan total anak ayam yang terpakai 100 ekor.

\section{Pemberian Ransum dan Air Minum}

Makanan diberikan tiga kali sehari (07.00, 12.00 dan 17.00 WIB) dan air minum diberikan adlibitum. Setiap ransum yang diberikan ditimbang sesuai dengan perlakauan.

\section{Pengukuran peubah yang diamati:}

Bobot hidup, dihitung dengan penimbangan bobot rata-rata ayam setiap perlakuan pada akhir penelitian.

Persentase lemak abdomen, perhitungan didasarkan atas penimbangan lemak dibawah rongga perut atau abdomen ( $f a t$ pad), kemudian dipersentasekan dengan bobot hidup. Lemak abdominal adalah lapisan lemak yang terdapat lapisan antara otot abdominal dan usus serta disekitar gizzard (Salam et al., 2013). Persentase lemak abdominal (g) diperoleh dengan membandingkan bobot lemak abdominal dengan bobot hidup (g) dikalikan $100 \%$.

Persentase karkas, pemotongan ayam tampa bulu, darah, kepala,l leher, lemak abdomen, organ dalam dan kaki (dipotong antara pertautan os tarsal dan os tabial) kecuali paru-paru dan ginjal kemudian dipersentasekan dengan bobot hidup.

$$
\text { Persentase karkas }=\frac{\text { bobot } \text { karkas }}{\text { bobot } \text { badan }} \times 100 \%
$$

Data yang diperoleh dianalisis secara statistik dengan menggunakan sidik ragam (Analysis of Variance/ANOVA). Perlakuan ysng pengruh nyata dilakukan DMRT (Duncan's Multiple Range Test) menurut Steel and Torrie (1980).

\section{HASIL DAN PEMBAHASAN}

\section{Bobot Hidup}

Penggunan DUKATF menggantikan sebagian ransum komersil CP Bravo 511 berdasarkan hasil analisis ragam menunjukkan bahwa berpengaruh sangat nyata $(\mathrm{P}<0,01)$ terhadap bobot hidup broiler umur 42 hari pemeliharaan (Tabel 3). Berdasarkan uji DMRT menunjukan bahwa bobot hidup pada perlakuan A, B, C, dan D berbeda tidak nyata $(\mathrm{P}>0,05)$, tetapi perlakuan $\mathrm{A}, \mathrm{B}, \mathrm{C}$, dan $\mathrm{D}$ ini berbeda nyata $(\mathrm{P}<0,05)$ dengan perlakuan $\mathrm{E}$.

Data diatas menunjukan bahwa penggunaan DUKATF menggantikan sebagian ransum komersil CP Bravo 511 dapat digunakan hingga $15 \%$ tanpa menurunkan bobot hidup. Penggunaan DUKATF sampai $20 \%$ dapat menurunkan bobot hidup. Hal ini 
JPI Vol. 22 (2): 199-210

Tabel 3. Rataan bobot hidup, persentase lemak abdomen, dan persentase karkas broiler

\begin{tabular}{lccc}
\hline \multirow{3}{*}{ Perlakuan } & \multicolumn{3}{c}{ Peubah yang diamati } \\
\cline { 2 - 4 } & $\begin{array}{c}\text { Bobot hidup } \\
(\mathrm{g} / \mathrm{e})\end{array}$ & $\begin{array}{c}\text { Persentase Lemak } \\
\text { Abdomen }(\%)\end{array}$ & $\begin{array}{c}\text { Persentase Karkas } \\
(\%)\end{array}$ \\
\hline A (0) & $2.203,50^{\mathrm{a}}$ & $1,49^{\mathrm{a}}$ & $62,64^{\mathrm{b}}$ \\
B (5) & $2.278,25^{\mathrm{a}}$ & $1,13^{\mathrm{a}}$ & $65,29^{\mathrm{a}}$ \\
$\mathrm{C}(10)$ & $2.196,00^{\mathrm{a}}$ & $0,97^{\mathrm{ab}}$ & $64,08^{\mathrm{a}}$ \\
D (15) & $2.160,00^{\mathrm{ab}}$ & $0,91^{\mathrm{b}}$ & $63,70^{\mathrm{a}}$ \\
E (20) & $2.055,50^{\mathrm{b}}$ & $0,91^{\mathrm{b}}$ & $62,67^{\mathrm{b}}$ \\
\hline SE & 47,64 & 0,11 & $0,57^{2}$ \\
\hline
\end{tabular}

Keterangan: ${ }^{a, b}$ Huruf kecil yang berbeda pada kolom yang sama pada masing-masing peubah menunjukkan pengaruh yang berbeda nyata $(\mathrm{P}<0,05)$; SE: Standar Eror.

disebabkan oleh semakin tinggi penggunaaan DUKATF menggantikan sebagian ransum komersil dapat menurunkan palatabelitas ransum terutama warna ransum menjadi lebih gelap, sehingga menurunkan kualitas ransum. Menurunnya kualitas ransum menurunkan konsumsi ransum, selanjutnya akan menurunkan pertambahan bobot badan maka menurunkan bobot hidup (Setiadi, 2012; Sari dan Anggraini, 2019).

Bobot hidup ayam yang didapat pada penelitian ini yaitu; 2.055,50-2.203,50 g/e (Tabel 3), hal ini hampir sama dibadingkan dengan bobot badan ayam umur 5 minggu dan lebih rendah dibandingkan dengan bobot hidup ayam Coob umur 6 standar Charoen Phokphand (2015) yaitu $2.191 \mathrm{~g} / \mathrm{e}$ dan 2.857 g/e. Bobot hidup ayam pada penelitian ini lebih tinggi dibandingkan penelitian Noferdiman (2009) yang melaporkan bobot hidup ayam broiler umur 4 minggu 1.043,05-2.064,37g/ e. Faktor-faktor yang mempengaruhi bobot hidup ayam yaitu konsumsi ransum, kualitas ransum, jenis kelamin, lama pemeliharaan, dan aktivitas. Hal ini karena adanya perbedaan kebutuhan nutrisi broiler pada umur yang berbeda. Faktor genetik dan lingkungan juga mempengaruhi laju pertumbuhan komposisi tubuh yang meliputi distribusi bobot, komposisi kimia, dan komponen karkas (Soeparno, 1994). Jenis ayam tidak mempengaruhi bobot dan persentase karkas (Hayati et al., 2019).

\section{Persentase Lemak Abdomen}

Penggunan produk DUKATF menggantikan sebagian ransum komersil $\mathrm{CP}$ Bravo 511 berdasarkan hasil analisis ragam menunjukan bahwa berpengaruh sangat nyata $(\mathrm{P}<0,01)$ terhadap persentase lemak abdomen broiler umur 42 hari pemeliharaan (Tabel 3). Berdasarkan uji DMRT persentase lemak abdomen perlakauan $\mathrm{A}, \mathrm{B}$, dan $\mathrm{C}$ tidak berbeda nyata $(\mathrm{P}>0,05)$, namun berbeda nyata $(p<0,05)$ dengan perlakuan $D$ dan $E$. Antar perlakuan D dan E tidak berbeda nyata $(\mathrm{P}>0,05)$.

Data diatas terlihat bahwa penggunaan DUKATF sebagai pengganti sebagian ransum komersil dapat digunakan sampai $15 \%$ efektif menurunkan persentase lemak abdomen. Bila ditingkatkan penggunaanya tidak efektif terhadap persentase penurunan lemak abdomen. Hal ini disebabkan oleh penggunaan DUKATF hingga 20\% menurunkan kualitas ransum dan energi ransum. Deschepper and Groote (1995) melaporkan bahwa broiler yang diberi ransum dengan protein yang semakin rendah akan meningkatkan lemak abdomen. Hal ini didukung oleh pendapat Deaton and Lott (1985) bahwa umur pemeliharaan dan energi ransum mempengaruhi persentase lemak abdomen. Disamping itu penggunaan hingga 20\% dapat menurunkan palatabilitas ransum terutama warna ransum, yang menyebabkan menurunnya kualitas ransum. Kualitas ransum menurun dapat menurunkan konsumsi ransum. Menurun konsumsi ransum 
makan akan menurun pula pengaruhnya dalam menurunkan persentase lemak abdomen.

Persentase lemak abdomen broiler umur 42 hari pada penelitian ini berkisar antara 3,55\% sampai 5,52\%. Hal ini sedikit berbeda dibanding Salam et al. (2013) bahwa persentase lemak abdominal karkas broiler umur 35 hari berkisar pada 0,73\% sampai $3,78 \%$, karena umur broilernya berbeda. Semakin lama pemeliharan semakin meningkat pelemakan dan penimbunan lemak yang terjadi pada ayam. bagian sekitar perut atau abdomen adalah Salah satu bagian tubuh yang digunakan untuk menyimpan lemak. Lohakare et al. (2004) melaporkan bahwa bobot lemak abdomen broiler umur enam minggu yaitu $2,7-2,94 \%$ dari bobot hidup dengan penambahan vitamin $\mathrm{C}$ dalam pakan dosis 10 dan 20 ppm. Bobot lemak abdomen hasil penelitian Ramli et al. (2002) yaitu $0,79 \%$ dari bobot hidup dengan penambahan teh fermentasi kambucha. Deschepper and Groote (1995) melaporkan bahwa broiler yang diberi ransum dengan protein yang semakin rendah akan meningkat lemak abdomen. Hal ini didukung oleh pendapat Deaton and Lott (1985) bahwa umur pemeliharaan dan energi ransum mempengruhi persentase lemak abdomen. Palo et al. (1995) menyatakan bahwa secara kuantitatif semakin pendek umur pemeliharaan, jumlah lemak abdomen karkas semakin menurun tetapi tidak memberikan efek yang nyata terhadap persentase bobot lemak abdomen. Menurut Maryuni dan Wibowo (2005) komposisi ransum anatara lain tingkat energi dalam ransum, perbandingan energi protein, dan kadar lemak ransum mempengaruhi penimbunan lemak. Kadar lemak dalam ransum juga akan berpengaruh terhadap penimbunan lemak ayam pedaging.

Deposisi lemak pada ayam broiler umumnya disimpan dalan bentuk lemak di rongga perut dan dibawah kulit. Penggunaan produk daun ubi kayu dan ampas tahu fermentasi dengan $R$. oligosporus terbaik menggantikan sebagian ransum komersil $\mathrm{CP}$ Bravo 511 hingga level 20\% berpengaruh nyata terhadap persentase lemak abdominal disebabkan oleh kandungan serat kasar produk DUKATF menggantikan sebagian ransum komersil CP Bravo 511. Lemak abdominal broiler dipengaruhioleh andungan serat kasar yang tinggi. Menurut Zuprizal dan Kamal (2005) bahwa serat kasar dalam pakan ayam broiler tidak boleh lebih dari 4-4,5\%. Persentase lemak abdominal pada level penggunaan 5-20\% cenderung menurun dibandingkan dengan perlakuan tanpa produk DUKATF menggantikan sebagian ransum komersil CP Bravo 511 (kontrol). Hal ini kemungkinan disebabkan karena adanya kandungan serat kasar dalam produk DUKATF menggantikan sebagian ransum komersil CP Bravo 511 sebesar 5\% (A), 5,33\% (B), 5,72\% (C), 6,10\% (D), 6,48 (E). Lemak abdominal dipengaruhi kandungan serat kasar yang tinggi (Mangunwidjaja et al., 2014). Menurut Poendjiadi (2005) bahwa serat kasar yang berasal dari pakan setelah dikonsumsi akan mengikat asam empedu di saluran pencernaan, sehingga menyebabkan akan terhambat fungsi empedu untuk membantu penyerapan lemak. Selanjutnya asam empedu yang sudah terikat oleh serat kasar akan dikeluarkan dari tubuh dalam bentuk feses mengakibatkan penurunan deposisi lemak abdominal. Hal ini sejalan dengan pendapat Sutardi (1992) bahwa serat dapat mengurangi absorsi lemak menyebabkan deposisi lemak ke dalam tubuh ayam tekan. Selanjutnya, Mahfudz et al. (2000) menambahkan untuk proses pencernaan serat kasar membutuhkan energi yang banyak menyebabkan ayam tidak memiliki energi yang berlebih untuk di simpan dalam bentuk lemak.

Rendahnya persentase lemak abdominal yang dihasilkan menunjukkan bahwa kondisi perlemakan yang dihasilkan cenderung akan lebih baik. Sebagaimana yang telah diketahui bahwa lemak abdominal adalah hasil ikutan yang dapat mempengaruhi kualitas karkas. Oleh karena itu semakin rendah persentasi lemak abdominal maka akan semakin baik karkas yang diperoleh. Hal ini sesuai dengan Yuniastuti (2002) bahwa tinggi rendahnya kualitas karkas broiler akan ditentukan dari 
jumlah lemak abdominal yang terdapat dari broiler. Mahfudz et al. (2009) menyatakan bahwa lemak abdominal dan lemak karkas memiliki hubungan korelasi positif, yaitu apabila lemak abdominal meningkat maka lemak karkas juga akan meningkat dan sebaliknya bila lemak abdomen menurun maka lemak karkas juga menurun, maka kualitas karkas akan meningkat. Semakin rendah lamak abdomen maka semakin bagus kualitas karkas.

\section{Persentase Karkas}

Penggunan DUKATF menggantikan sebagian ransum komersil CP Bravo 511 berdasarkan analisis ragam menunjukan bahwa berpengaruh sangat nyata $(\mathrm{P}<0,01)$ terhadap persentase karkas broiler umur 42 hari pemeliharaan (Tabel 3). Berdasarkan uji DMRT menunjukkan bahwa persentase karkas perlakuan $\mathrm{A}$ berbeda nyata $(\mathrm{P}<0,05)$ dengan perlakuan $\mathrm{B}, \mathrm{C}$, dan $\mathrm{D}$, namun perlakuan $\mathrm{A}$ ini tidak berbeda nyata $(\mathrm{P}>0,05)$ dengan perlakuan $\mathrm{E}$.

Data diatas menunjukan bahwa penggunan DUKATF menggantikan sebagian ransum komersil $\mathrm{CP}$ Bravo 511 dapat digunakan hingga $15 \%$ tanpa menurunkan persentase karkas. Penggunaan DUKATF hingga $20 \%$ dapat menurunkan persentase karkas, karena dapat menurunkan palatabilitas ransum menyebabkan menurunnya konsumsi. Penurunan konsumsi menyebabkan menurunnya pertambahan bobot badan dan bobot akhir, sehingga juga dapat menurunkan persentase karkas. Penurunan persentase karkas juga ada hubungannya dengan lemak abdomen. Semakin rendah lemak abdomen semakin tinggi persentase karkas. Persentase karkas juga dipengaruhi oleh bobot hidup. Hal ini karena, persentase bagian-bagian karkas berhubungan erat dengan bobot karkas, sedangkan bobot karkas akan dipengaruhi oleh bobot hidup (Suswono et al., 1992).

Persentase karkas pada penelitiaan ini berkisar $62,67-65,29 \%$. Hasil penelitiaan ini lebih tinggi dibandingkan pendapat Sari et al. (2014) bahwa nilai rataan persentase karkas broiler yang dipelihara selama 35 hari yaituberkisar $27,14 \%$ sampai $28,48 \%$.

\section{KESIMPULAN}

Penggunaan produk fermentasi daun ubi kayu dan ampas tahu (DUKATF) dengan $R$. oligosporus terbaik menggantikan sebagian ransum komersil CP Bravo 511 terhadap kualitas karkas terbaik berdasarkan bobot hidup, persentase karkas, persentase lemak abdomen adalah $15 \%$.

\section{UCAPAN TERIMA KASIH}

Penelitian ini didanai oleh Kementerian Riset Teknologi dan Pendidikan Tinggi Republik Indonesia di bawah program PMDSU NO. 050/SP2H/LT/DRPM/2018. Kami sangat berterima kasih kepada Kementerian Teknologi Riset dan Pendidikan Tinggi Republik Indonesia dan Rektor Universitas Andalas atas dukungan dalam program ini.

\section{DAFTAR PUSTAKA}

Adrizal., Heryandi, Y., Amizar, R. and Mahata, M. E. 2017. Evaluation of pineapple [Ananas comosus (L.) Merr] waste fermented using different local microorganism solutions as poultry feed. Pakistan Journal Nutrition, 16: 84-89.

Aisjah, T. 2012. Bioprocess of winged bean seeds (Psophocarpus tetragonolobus (1) dc) by Rhizopus oligosporus to improve of pure protein content and decreased of cyanide. Journal of Animal Science (Jurnal Ilmu Ternak) Universitas Padjadjaran, 12(1): 35-40.

Annisa., Rizal, Y., Mirnawati., Suliansyah, I. and Bakhtiar, A. 2020a. Determination of the Appropriate Ratio of Rice Bran to Cassava Leaf Meal Mixture as anInoculum of $R$. oligosporus in 
Broiler Ration. Journal of World's Poultry Research, 10(1).

Annisa., Rizal, Y., Mirnawati., Suliansyah, I. and Bakhtiar, A. 2020b. Determination of the Appropriate Inoculum Dosa and Incubation Time of Mixture Cassava leaf and Tofu Dreg of Fermentation with $R$. oligosporus. World's Veterinary Journal, 10(1).

Avrianti, S., Muslim, dan I. Siska. 2019. Pengaruh substitusi ransum komersil dengantepung daun trembesi (Samanea saman) terhadap bobot hidup, persentase karkas dan persentase lemak abdominal ayam broiler. Jurnal Green Swarnadwipa, 1: 33-38.

Badan Pusat Statistik. 2018. sumbar.bps. go.id/dynamictable/2016/12/13/84/ produksi-ubi-kayu-provinsi-sumaterabarat-menurut-kabupaten-kotaton-2000-2015.html

Chambers, J. R., A. Fortin, and A. A. Grunder. 1983. Relationships between carcass fatness and feed efficiency and its component traits in broiler chickens. Poult. Sci. 62: 2201-2207.

Charoen Pokphand Indonesia. 2015. Manajemen broiler modern. Kiat-kiat memperbaiki FCR. Technical Service dan Development Departement, Jakarta.

Deaton, J. W. and B. D. Lott. 1985. Age and dietary energy effect on broiler abdominal fat deposition. Poultry Science. 4: 2161-2164.

Deschepper, K. and G. De. Groote. 1995. Effect of dietary protein essential and non essential amino acid in the performance and carcass compotition of male broiler chickens. British Poultry Science. 36: 229-245.

Dewi, S. 2015. Isolation and identification of cellulolytic thermophilic fungi and examination of its cellulase enzyme activity. Thesis. Faculty of Agricultural Technology. Gadjah Mada University. Yogyakarta.
Dewi, Y.L., Yuniza, A., Nuraini., Sayuti, K. and Mahata, M.E. 2019. Fermentation of Sargassum binderi Seaweed for Lowering Alginate Content of Feed in Laying Hens. Journal of World's Poultry Research. 9(3): 147-153.

Eggum, B. O. 1970. The Protein Quality of Cassava Leaves. The British Journal of Nutrition, 24(3): 761-768.

Griffiths, L., S. Leeson, and J. D. Summer. 1978. Studies on abdominal fat with four commercial strain of male broiler chicken. Poult. Sci. 52: 1198-1203.

Han, B., Ma Y., M. Frans., M. J. Rombouts, and N. Robert. 2003. Effects of temperature and relative humidity on growth and enzyme production by action mucorelegans and $R$. oligosporus during sufupehtze preparation. Food Chem. 81: 27-34.

Hayati, S. N., Mulyono, S. dan Roesdiyanto. 2019. Bobot dan Persentase Karkas berbagai Jenis Ayam Sentul Jantan Periode Awal. Jurnal Peternakan Indonesia, 21(3): 240-246.

Iheukwumere, F. C., E. C. Ndubuisi., E. A. Mazi, and M. U. Onyekwere. 2008. Performance, Nutrient Utilization and Organ Characteristics of Broilers Fed Cassava Leaf Meal (Manihot esculenta Crantz). Pakistan Journal of Nutrition, 7(1): 13-16.

Kurnia, D. R. 2010. Studi aktivitas enzim lipase dari Aspergillus niger sebagai biokatalis dalam proses gliserolisis untuk menghasilkan monoasilgliserol. Doctoral dissertation, Universitas Diponegoro, Semarang.

Lohakare, J. D., B. J. Chae, and T. W. Hahn. 2004. Effects of feeding methods (water vs. feed) of vitamin $\mathrm{C}$ on growth performance and carcass characteristics in broiler chickens. Asian-Australasian Journal of Animal Science. 17(8): 1112- 1117.

Mahfudz, L. D., W. Sarengat, dan B. Srigandono. 2000. Penggunaan 
ampas tahu sebagai bahan penyususn ransum broiler. Prosiding Seminar Nasional Pengembangan Peternakan Lokal, Universitas Jendral Sudirman, Purwokerto.

Mahfudz, L. D., F. L. Maulana., U. Atmomarsono, dan T. A. Sarjana. 2009. Karkas dan lemak abdominal ayam broiler yang diberi ampas bir dalam ransum. Seminar Kebangkitan Peternakan. Pemberdayaan Peternakan Berbasis Sumber Daya Lokal untuk Ketahanan Pangan Berkelanjutan. Semarang.

Mangunwidjaja, D., M. Rahayuningsih, dan R. Suparwati. 2014. Pengaruh konsentrasi enzim dan waktu hidrolisis enzimatis terhadap mutu fruktooligosakarida dari inulin umbi dahlia (Dahlia pinnata). E-Jurnal Agroindustri Indonesia, 3(2): 1-13.

Maryuni, S. S. dan C. H. Wibowo. 2005. Pengaruh kandungan lisis dan energy metabolis dalam ransum yang mengandung ubi kayu fermentasi terhadap konsumsi ransum dan lemak ayam broiler. J. Indon. Trop. Anim. Agric. 30(1): 26-33.

Melesse. A., Masebo, M. and Abebe, A. 2018. The substitution effect of noug seed (Guizotia abyssinica) cake with cassava leaf (Manihot escutulata Crantz.) meal on feed intake, growth performance, and carcass traits in broiler chickens. Journal of Animal Husbandry and Dairy Science, 2(2): 1-9.

Mirnawati, R. Y., Marlida, Y. and Kompiang, I. P. 2010. The role of humic acid in palm kernel cake fermented by Aspergillus niger for poultry ration. Pakistan Journal of Nutrition, 9(2): 182-185.

Mirnawati., Ciptaan, G. and Ferawati. 2017. The effect of Mananolytic fungi and humic acid dosage to improve the nutrient content and quality of fermented palm kernel cake. International journal of Chemistry Technology Research,
10(2): 56-61.

Mirnawati., Ciptaan, G. and Ferawati. 2019a. Improving the quality and nutrient content of palm kernel cake through fermentation with Bacillus subtilis. International Journal of Animal and Veterinary Sciences, 31(7): 1-9.

Mirnawati., Ciptaan, G. and Ferawati. 2019b. The Effect of Bacillus subtilis Inoculum Doses and Fermentation Time on Enzyme Activity of Fermented Palm Kernel Cake. Journal of World's Poultry Research, 9(4): 211-216.

Mirnawati., Djulardi, A. and Ciptaan, G. 2018. Utilization of fermented palm kernel cake with Sclerotium rolfsii in broiler ration. International Journal of Poultry Science. 17(7): 342-347.

Mirnawati., Djulardi, A. and Marlida, Y. 2013. Improving the quality of palm kernel cake fermented by Eupenicillium javanicum as poultry ration. Pakistan Journal of Nutrition, 12(12): 10851088.

Mirnawati., Kompiang, I. P. and Latif, S. A. 2012. Effect of substrate composition and inoculums dosage to improve quality of palm kernel cake fermented by Aspergillus niger. Pakistan Journal of Nutrition, 11(5): 434-438.

Noferdiman. 2009. Peningkatan mutu lumpur sawit melalui fermentasi dengan jamur Phanerochaete chrysosporium serta pemanfaatannya dalam ransum ayam broiler. Disertasi, Universitas Andalas. Padang.

Nuraini., S. A. Latif, dan Sabrina. 2009. Improving the quality of tapioka by paoduct thrugh fermentation by Neurospora crassa to produce $\beta$ caroten rich feed. Pakistan Journal of nutrition, 8(4): 487-490.

Palo, P. E., J. L. Sell., F. J. Piguer., M. F. Salanova, dan L. Vilaseca. 1995. Effect of early nutrient restriction on broiler chicken: Performance and development of the gastrointestinal tract. Poultry 
Science. 74: 88-101.

Poendjiadi, A. 2005. Dasar - Dasar Biokimia, Jakarta (Indonesia): UI Pres.

Purkan, P., Baktir, A. and Sayyidah, A. R. 2016. Produksi Enzim Kitinase dari Aspergillus Niger Menggunakan Limbah Cangkang Rajungan sebagai Induser. Journal Kimia Riset, 1(1): 3441.

Ramli, N., M. Nasir, R. dan Sindu, A. 2002. Pengaruh teh fermentasi kombucha sebagai feed aditif terhadap persentase karkas, lemak abdomen, dan organ dalam ayam broiler. Seminar Nasional Teknologi Peternakan dan Veteriner, Pusat Penelitian dan Pengembangan Peternakan, Bogor.

Ravindran, V. 1991. Preparation of cassava leaf product and their use as animal feeds. Proceedings of the FAO expert consultation CIAT, Cali, Columbia. 2125: 81-95.

Rizal, Y., Mahata, M. E., Joli, I. and Wu, G. 2012. Improving the nutrient quality of juice wastes mixture through fermentation by using Trichoderma viridae for poultry diet. Pakistan Journal of Nutrition, 11 (3): 203-207.

Rizal, Y., Nuraini., Mirnawati, and Mahata, M. E. 2013. Comparisons of nutrients contents and nutritional values of palm kernel cake fermented by using different fungi. Pakistan Journal of Nutrition, 12 (10): 943-948.

Salam, S., A. Fatahilah., D. Sunarti, dan Isroli. 2013. Bobot karkas dan lemak abdominal broiler yang diberi tepung jintan hitam (Nigella sativa) dalam ransum selama musim panas. Jurnal Sains Peternakan, 11 (2): 84-89.

Sari, Y. P. dan Y. L. Anggraini. 2019. Pengaruh substitusi tepung kulit tauge fermentasi dalam ransum komersial terhadap bobot hidup, persentase karkas dan persentase lemak abdominal ayam broiler strain CP 707. Journal of Animal Center, 1(2):105-123.
Sari, M. L., F. N. L. Lubis, dan L. D. Jaya. 2014. Pengaruh Pemberian Asap Cair Melalui Air Minum Terhadap Kualitas Karkas Ayam Broiler. Agripet, 1(14): 71-75.

Setiadi, D. 2012. Perbandingan bobot hidup, karkas, giblet, dan lemak abdominal ayam jantan tipe medium dengan strain berbeda yang diberi ransum komersil broiler. Skripsi. Fakultas Pertanian, Universitas Lampung. Lampung.

Soeparno. 1994. Ilmu dan Teknologi Daging. Gadjah Mada University Press. Yogyakarta.

Soeprijanto., Ratnaningsih, T. and Prasetyaningrum. 2008. Bioconversion of cellulose from corn cob waste to glucose using Aspergillus niger mushroom. Purification Journal, 9(2):105-114.

Steel, R. G. D. and Torrie, J. H. 1980. Principles and Procedures of Statistics: A Biometrical Approach. 2nd edition. New York, USA: (McGraw-Hill, Inc). pp. 187-188 and 336-376.

Sudaryanto, B., I. N. Rangkuti, dan A. Prabowo. 1982. Penggunaan tepung daun singkong dalam ransum babi. BPT Ciawi, Bogor.

Sugiharto, S. 2019. A review on fungal fermented cassava pulp of as a cheap alternative feedstuff in poultry ration. Journal of world's poultry research, 9(1): 01-06.

Sumiati., Farhanuddin., W. Hermana., A. Sudarman., N. Istichomah, dan A. Setiyono. 2011. Penampilan ayam broiler diberi ransum tepung biji jarak pagar (Jatropha curcas 1.) yang difermentasi menggunakan $R$. oligosporus. Media Peternakan, 34(2): 117-125.

Suparti, S., I. Mangisah, dan B. Sukamto. 2019. Penggunaan Lactobacillus sp dan mikropartikel tepung cangkang telur terhadap kecernaan lemak dan massa lemak daging ayam broiler. Thesis, 
Fakultas Peternakan, Universitas Diponogoro.

Suswono, I., Rosidi, dan E. Tugiyanti. 1992. Bagian-bagian karkas ayam broiler dibawah pengaruh lantai kandang dan frekuensi pemberian pakan yang berbeda. Laporan Hasil Penelitian. Fakultas Peternakan Unsoed. Purwokerto.

Sutardi. 1992. Pengawetan Pangan: Pendinginan dan Pengeringan. PAU Pangan dan Gizi. Universitas Gadjah Mada, Yogyakarta.

Wyllie, D. and P. J. Chamanga. 1979. Cassava Leaf Meals in Broiler Diets. Tropical Animal Production. 4(3): 232-240.

Yuniastuti, A. 2002. Efek pakan berserat pada ransum ayam terhadap kadar lemak dan kolesterol daging broiler. JITV, 9(3):
175-183.

Yuniza, A., Nova, T. D., Angga, W. A., Annisa, dan Rizal. Y. 2016. Effects of the combinations of cassava leaf meal and palm kernel cake mixture fermented by Bacillus amyloliquefaciens on the alteration of their dry matter, crude protein, crude fiber, and crude lipid contents. Pakistan Journal of Nutrition, 15: 1049-1054.

Zakaria, Y., Novita, C. I. and Samadi, S. 2013. The effectiveness of fermentation with different substrate sources on the quality of rice straw. Jurnal Agripet, 13(1): 22-25.

Zuprizal dan M. Kamal. 2005. Nutrisi dan Pakan Unggas. Jurusan Nutrisi dan Makanan Ternak Fakultas Peternakan UGM. Yogyakarta. 